\title{
Studies on Character Association, Path Analysis and Genetic Variability in Rice (Oryza sativa) Genotypes
}

\author{
S.K. Singh, Prudhvi Raj Vennela*, Rajesh Singh, Varsha Gayatonde and D.K. Singh
}

Department of Genetics and Plant Breeding, Institute of Agricultural Sciences, BHU, Varanasi-221005 U.P., India

*Corresponding author

\begin{tabular}{|l|}
\hline K e y w o r d s \\
$\begin{array}{l}\text { Character association, } \\
\text { GCV, Genetic variability, } \\
\text { Heritability, Path analysis } \\
\text { and PCV }\end{array}$ \\
\hline Article Info \\
\hline $\begin{array}{l}\text { Accepted: } \\
\text { 20 April } 2018 \\
\text { Available Online: } \\
\text { 10 May } 2018\end{array}$ \\
\hline
\end{tabular}

\section{A B S T R A C T}

In the present investigation 50 rice genotypes were used to study character association, path analysis and variability. The studies of variance among 50 genotypes for ten characters revealed that the genotypes differed significantly for all the characters under study. PCV was recorded highest for plant height (22.93) followed by effective tillers/plant (21.60) and biomass per plant (18.35). Low magnitude of PCV was exhibited by harvest index (9.28) followed by 1000 grain weight (9.99) and days to maturity (10.16). GCV was also high for plant height (22.90) followed by biomass (16.96) and grain yield per plant (16.77). Whereas, low magnitude of GCV was exhibited by harvest index (6.99) followed by 1000 grain weight (9.52) and days to maturity (10.10). The highest heritability was found in days to $50 \%$ flowering, days to maturity and plant height (99\%) followed by spikelet fertility (95\%) and panicle length (93\%). Lowest heritability was observed in effective tillers/plant (55\%) followed by harvest index (56\%). Genetic advance as percent of mean (5\%) was realized highest for plant height (47.12) followed by biomass (32.29) and grain yield per plant (32.10). Lowest value was observed in harvest index (10.85) followed by 1000 grain weight (18.69) and days to maturity (20.70).

\section{Introduction}

Rice (Oryza sativa L.) is an important crop which belongs to genus Oryza of Poaceae family. There is evidence suggesting that rice was the first crop domesticated by humans in the Yangtze river basin as early as 13000 years ago (Lu et al., 2002). The genus Oryza has twenty two wild and two cultivated species namely; Oryza sativa and Oryza glaberrima, all the germplasm found in Asia, America and Europe belongs to Oryza sativa, and while in West Africa belong to Oryza glaberrima. Oryza sativa is a cultivated diploid species having 24 chromosomes. The sativa rice is commonly divided into three sub-species i.e. Indica, Japonica and Javanica.

Presently rice is grown in more than 114 countries over 165.4 million ha area with the total annual production of 758.1 million tonnes (Ezuka and Kaku, 2000; FAO, 2017). India is the world's second largest producer of rice after China with a production of 210.10 million tonnes of rice on an area of 43.97 
million hectares (mha) and with average productivity of 24.04 quintal per hectare (Directorate of Economics and Statistics, 2017). However, rice yield is growing at a pace of around $1 \%$ now, which means that global rice production by 2050 will grow by only $42 \%$ to around 705 million tons, says the study (http://www.oryza.com). The best alternative strategy to supplement this is to increase the productivity of rice by minimizing the impact of biotic and abiotic stresses which come in the way of rice production. Plant breeding is the most important tool for alleviating both biotic and Abiotic stresses. The foremost goal of plant breeders is to bridge the gap between food requirements and growing population, which requires the development of appropriate technologies for sustainable agriculture productivity (Madhavilatha, 2007).

Genetic variability for agronomic traits is the key component of breeding programs for broadening the gene pool of rice and would require reliable estimates of heritability in order to plan an efficient breeding program (Akinwale et al., 2011). Yield component breeding to increase grain yield would be most effective, if the components involved are highly heritable and genetically independent or positively correlated with grain yield. However, it is very difficult to judge whether observed variability is highly heritable or not. Moreover, knowledge of heritability is essential for selection based improvement as it indicates the extent of transmissibility of a character into future generations (Sabesan et al., 2009). The advantage of path analysis is that it permits the partitioning of the correlation coefficient into its components, one component being the path coefficient that measures the direct effect of a predictor variable upon its response variable; the second component being the indirect $\operatorname{effect}(\mathrm{s})$ of a predictor variable on the response variable through another predictor variable.

\section{Materials and Methods}

The present investigation was carried out at the Agricultural Research Farm, Banaras Hindu University, Varanasi, (India) during the kharif 2015 cropping season. Experimental material consisting of 50 rice genotypes (Table 1) was grown in three rows of $3.0 \mathrm{~m}$ with three replications in RBD with spacing of $20 \mathrm{x} 15 \mathrm{~cm}^{2}$. Recommended agronomic practices were followed to raise a good crop. Observations were recorded on five randomly selected plants for estimation of mean with respect to ten quantitative traits viz., days to flowering (DF), days to maturity (DTM), plant height $(\mathrm{PH})(\mathrm{cm})$, effective tillers/plant $(\mathrm{ETP})$, panicle length $(\mathrm{PL})(\mathrm{cm})$, spikelet fertility $(\mathrm{SF})$ (\%), 1000- grain weight (g), grain yield plant/ plant (GYP) (g), biomass and harvest index (HI).

The analysis of variance was done as suggested by Panse and Sukhatme (1967). Genotypic coefficient of variation (GCV), phenotypic coefficient of variation (PCV) and heritability were estimated by formula suggested by Burton (1952). Genetic advance (GA) was calculated by the method suggested by Johnson et al., (1955). The genotypic and phenotypic correlation coefficients were worked out by adopting method described by Singh and Chaudhary (1977). Path coefficient analysis was done according to the procedure suggested by Dewey and Lu (1959). The data was analyzed by Windostat version 9.2 with indostat services.

\section{Results and Discussion}

The analysis of 10 traits was carried out to partition the total variation into genotypic variation and variation due to other sources. Analysis of variance was based on the mean values of ten quantitative traits in 50 rice genotypes. The ANOVA of ten traits is presented in Table 2. 


\section{Analysis of mean performance and range}

Mean of replication is calculated by taking the average of five randomly selected plants of each genotype. Similarly mean of the other two replications were also considered and a final mean was calculated from these three data. The mean performance and range of all the characters under study among 50 genotypes are presented in Table 3 .

\section{Days to $50 \%$ flowering}

Days to $50 \%$ flowering ranged from 78 to 120 days. The average mean for this trait was 94 days. The early flowering was seen in genotype NDR-97 (78 days) while genotypes GR-32 \& ADAMCHINI (120 days) exhibited late days to $50 \%$ flowering followed by MTU7029 (116 days).

\section{Days to maturity}

Days to maturity varied from 106 to 150 days with a mean value of 121 days. The highest days to maturity was observed in genotype ADAMCHINI (150 days) followed by MTU7029 (147 days). While, lowest in genotypes NDR 97 and URG-8 (106 days) followed by URG 5(107 days).

\section{Plant height}

Plant height ranged from $79.87 \mathrm{~cm}$ to 199.39 $\mathrm{cm}$ with a mean value of $110.59 \mathrm{~cm}$. Among all genotypes URG-1 (79.87) was the shortest followed by URG-8 (85.26) whereas, KHUTADHAN (199.39) was having highest plant height followed by GR 32 (169.41).

\section{Number of effective tillers per plant}

The mean values of genotypes ranged from 4 to 8 with a general mean of 6 . The highest number of effective tillers per plant was observed in genotypes MTU-1010, MTU
7029, RAJENDRA KASTHURI, HUR 917 and IET-22202 (8 No.) whereas lowest value was registered in three genotypes i.e. URG-41 and URG-1(4 No.).

\section{Spikelet fertility \%}

Spikelet fertility \% ranged from $61.0 \%$ to $89.0 \%$. The average spikelet fertility was observed $77.10 \%$. The highest spikelet fertility $\%$ was recorded in DANTESHWARI and HUR 2-1 (89.0\%) and lowest value was found in URG $30(61.0 \%)$ followed by ANJALI $(62.0 \%)$.

\section{Panicle length (cm)}

Panicle length ranged from $19.40 \mathrm{~cm}$ to 35.10 $\mathrm{cm}$ with a mean value of $26.00 \mathrm{~cm}$.

The longest panicle length was observed in GR $32 \quad(35.10 \mathrm{~cm})$ followed by AKSHYADHAN $(31.58 \mathrm{~cm})$, while the shortest panicle was found in genotype RRHZ-7 (19.40 cm) followed by BD-105 $(21.28 \mathrm{~cm})$.

\section{0-grain weight (g)}

This value ranged from 16.05 to $26.90(\mathrm{~g})$. The highest mean value for 1000 grain weight was registered in genotype BARANIDEEP $(26.90 \mathrm{~g})$ followed by IET-22202 (25.75 g), whereas lowest grain weight was observed in genotype ADAMCHINI (16.05 g). The mean of 1000-grain weight was $23.43 \mathrm{~g}$.

\section{Grain yield per plant (g)}

Data for Grain yield per plant ranged from $10.74 \mathrm{~g}$ to $24.63 \mathrm{~g}$. Highest grain yield was observed in genotype MTU-7029 (24.63 g) followed by IR $64(23.51 \mathrm{~g})$ whereas lowest grain yield was observed in genotype BG 102 $(10.74 \mathrm{~g})$. The average mean for this trait was $17.93 \mathrm{~g}$. 
Table.1 List of genotypes selected for $\mathrm{D}^{2}$ analysis

\begin{tabular}{|c|c|c|c|}
\hline S. No. & Genotype & S. No. & Genotype \\
\hline 1 & MTU-1010 & 26 & GR-32 \\
\hline 2 & SAHBHAGIDHAN & 27 & HUR 917 \\
\hline 3 & NDR-97 & 28 & IET-22202 \\
\hline 4 & NDR-359 & 29 & URG-5 \\
\hline 5 & SARJU-52 & 30 & URG-42 \\
\hline 6 & HUR-105 & 31 & URG-1 \\
\hline 7 & HUR-3022 & 32 & URG-30 \\
\hline 8 & BPT-5204 & 33 & URG-8 \\
\hline 9 & MTU-7029 & 34 & URG-19 \\
\hline 10 & VANDANA & 35 & URG-22 \\
\hline 11 & ANJALI & 36 & BG-102 \\
\hline 12 & TARORI BASMATI & 37 & ADAMCHINI \\
\hline 13 & $\mathrm{~N}-22$ & 38 & PANTDHAN-12 \\
\hline 14 & HUBR 10-9 & 39 & IET-22225 \\
\hline 15 & DANTESHWARI & 40 & IET-20556 \\
\hline 16 & SUSKSAMARAT & 41 & IR-36 \\
\hline 17 & BARANIDEEP & 42 & IR-64 \\
\hline 18 & VARDHAN & 43 & URG-3 \\
\hline 19 & TYPE-3 & 44 & URG-24 \\
\hline 20 & RAJENDRA KASTHURI & 45 & BD-105 \\
\hline 21 & KARHANI & 46 & HUR 5-2 \\
\hline 22 & KHUTADHAN & 47 & CGZR-1 \\
\hline 23 & PANTDHAN-4 & 48 & R-RHZ-7 \\
\hline 24 & AKASHYADHAN & 49 & NDR-2104 \\
\hline 25 & HUR 2-1 & 50 & NDR-2064 \\
\hline
\end{tabular}


Table.2 ANOVA of all the traits - Genetic Parameters (Summary)

\begin{tabular}{|c|c|c|c|c|c|c|c|c|c|c|}
\hline & DF & DTM & PH (cm) & ET/P & SF $(\%)$ & $\begin{array}{c}\text { PL } \\
(\mathrm{cm})\end{array}$ & $\begin{array}{c}\text { 1000GW } \\
\text { (g) }\end{array}$ & $\begin{array}{c}\text { GY/ } \\
\text { Plant (g) }\end{array}$ & $\begin{array}{c}\text { Biomass } \\
\text { (g) }\end{array}$ & HI (\%) \\
\hline Var. Environmental & 0.913 & 1.664 & 1.734 & 0.742 & 3.302 & 0.71 & 0.461 & 1.44 & 6.77 & 8.559 \\
\hline ECV & 1.021 & 1.066 & 1.191 & 14.373 & 2.357 & 3.24 & 3.026 & 6.692 & 7.017 & 6.103 \\
\hline Var. Genotypical & 127.351 & 149.604 & 641.712 & 0.934 & 65.203 & 9.709 & 4.559 & 9.052 & 39.578 & 11.233 \\
\hline GCV & 12.065 & 10.107 & 22.906 & 16.125 & 10.474 & 11.984 & 9.522 & 16.777 & 16.965 & 6.992 \\
\hline Var. Phenotypical & 128.264 & 151.268 & 643.446 & 1.676 & 68.505 & 10.419 & 5.02 & 10.492 & 46.348 & 19.792 \\
\hline PCV & 12.108 & 10.163 & 22.937 & 21.601 & 10.736 & 12.414 & 9.991 & 18.062 & 18.359 & 9.281 \\
\hline $\mathbf{h}^{2}$ (Broad Sense) & 0.993 & 0.989 & 0.997 & 0.557 & 0.952 & 0.932 & 0.908 & 0.863 & 0.854 & 0.568 \\
\hline $\begin{array}{l}\text { Genetic Advancement } \\
5 \%\end{array}$ & 23.164 & 25.057 & 52.114 & 1.486 & 16.228 & 6.196 & 4.192 & 5.757 & 11.976 & 5.201 \\
\hline $\begin{array}{l}\text { Genetic Advancement } \\
1 \%\end{array}$ & 29.686 & 32.112 & 66.786 & 1.905 & 20.798 & 7.941 & 5.372 & 7.378 & 15.348 & 6.666 \\
\hline $\begin{array}{l}\text { Gen.Adv as \% of Mean } \\
5 \%\end{array}$ & 24.766 & 20.706 & 47.123 & 24.798 & 21.05 & 23.831 & 18.694 & 32.1 & 32.295 & 10.851 \\
\hline $\begin{array}{l}\text { Gen.Adv as \% of Mean } \\
1 \%\end{array}$ & 31.739 & 26.536 & 60.391 & 31.779 & 26.977 & 30.541 & 23.957 & 41.138 & 41.388 & 13.907 \\
\hline General Mean & 93.533 & 121.013 & 110.591 & 5.993 & 77.093 & 26.002 & 22.425 & 17.934 & 37.082 & 47.933 \\
\hline $\begin{array}{l}\text { Exp Mean next } \\
\text { Generation }\end{array}$ & 116.698 & 146.071 & 162.704 & 7.48 & 93.322 & 32.198 & 26.617 & 23.691 & 49.058 & 53.135 \\
\hline
\end{tabular}


Int.J.Curr.Microbiol.App.Sci (2018) 7(5): 2702-2712

Table.3 Mean performance of different genotypes for different traits

\begin{tabular}{|c|c|c|c|c|c|c|c|c|c|c|c|}
\hline S. No. & Genotypes & DF & DTM & $\begin{array}{l}\text { PH } \\
\text { (cm) }\end{array}$ & ET/P & $\begin{array}{c}\text { SF } \\
(\%)\end{array}$ & $\begin{array}{l}\text { PL } \\
(\mathrm{cm})\end{array}$ & $\begin{array}{c}1000 \\
\text { GW(g) }\end{array}$ & $\begin{array}{c}\text { GY/ } \\
\text { Plant (g) }\end{array}$ & $\begin{array}{c}\text { Biomas } \\
\mathrm{s}(\mathrm{g})\end{array}$ & HI (\%) \\
\hline 1 & MTU-1010 & 92 & 118 & 98.22 & 8 & 87.0 & 25.52 & 22.07 & 22.23 & 39.44 & 52.33 \\
\hline 2 & SAHBHAGIDHAN & 86 & 111 & 98.48 & 6 & 76.0 & 27.35 & 24.70 & 17.37 & 36.88 & 47.00 \\
\hline 3 & NDR-97 & 78 & 106 & 83.16 & 5 & 72.0 & 24.58 & 22.00 & 16.39 & 35.52 & 46.33 \\
\hline 4 & NDR-359 & 98 & 125 & 98.56 & 6 & 70.0 & 28.70 & 24.30 & 19.30 & 43.13 & 45.00 \\
\hline 5 & SARJU-52 & 100 & 126 & 104.38 & 6 & 88.0 & 29.62 & 24.03 & 21.82 & 43.90 & 49.67 \\
\hline 6 & HUR-105 & 103 & 129 & 95.94 & 7 & 81.0 & 23.88 & 23.61 & 23.15 & 44.60 & 52.00 \\
\hline 7 & HUR-3022 & 90 & 127 & 104.28 & 7 & 83.0 & 29.61 & 21.77 & 19.33 & 36.76 & 52.67 \\
\hline 8 & BPT-5204 & 114 & 144 & 85.33 & 7 & 84.0 & 21.76 & 22.87 & 22.43 & 44.80 & 50.33 \\
\hline 9 & MTU-7029 & 116 & 147 & 90.77 & 8 & 83.3 & 22.77 & 24.27 & 24.63 & 48.58 & 51.00 \\
\hline 10 & VANDANA & 86 & 111 & 106.48 & 6 & 67.0 & 23.02 & 23.17 & 15.61 & 28.16 & 52.67 \\
\hline 11 & ANJALI & 80 & 106 & 111.38 & 6 & 62.0 & 26.90 & 24.27 & 16.00 & 28.43 & 53.33 \\
\hline 12 & TARAWARI BASMATI & 109 & 137 & 167.30 & 5 & 73.0 & 27.83 & 22.20 & 16.85 & 40.59 & 41.33 \\
\hline 13 & $\mathrm{~N}-22$ & 83 & 110 & 107.40 & 5 & 71.0 & 22.64 & 19.87 & 15.27 & 28.71 & 53.33 \\
\hline 14 & HUBR 10-9 & 97 & 125 & 121.27 & 6 & 84.0 & 27.00 & 23.00 & 17.84 & 32.98 & 51.33 \\
\hline 15 & DANTESHWARI & 85 & 111 & 85.26 & 5 & 89.0 & 27.65 & 24.83 & 16.79 & 29.40 & 50.00 \\
\hline 16 & SUSKSAMARAT & 95 & 122 & 103.78 & 5 & 87.0 & 27.18 & 25.70 & 16.90 & 29.97 & 52.33 \\
\hline 17 & BARANIDEEP & 102 & 128 & 103.54 & 6 & 72.0 & 28.74 & 26.90 & 20.07 & 40.41 & 49.67 \\
\hline 18 & VARDHAN & 86 & 108 & 117.23 & 6 & 85.0 & 25.00 & 21.43 & 15.35 & 31.14 & 49.00 \\
\hline 19 & TYPE-3 & 94 & 117 & 143.40 & 6 & 73.0 & 28.41 & 23.93 & 20.76 & 49.36 & 41.67 \\
\hline 20 & RAJENDRA KASTHURI & 107 & 135 & 107.30 & 8 & 84.7 & 22.07 & 21.43 & 19.55 & 40.37 & 48.33 \\
\hline 21 & KARHANI & 83 & 121 & 112.93 & 5 & 79.0 & 21.43 & 22.81 & 14.67 & 31.09 & 47.00 \\
\hline 22 & KHUTADHAN & 103 & 134 & 199.39 & 5 & 75.0 & 28.67 & 22.42 & 16.86 & 38.35 & 44.00 \\
\hline 23 & PANTDHAN-4 & 94 & 122 & 108.43 & 6 & 78.0 & 29.00 & 21.49 & 18.03 & 37.84 & 47.67 \\
\hline 24 & AKASHYADHAN & 97 & 123 & 111.70 & 5 & 80.7 & 31.58 & 25.15 & 22.30 & 45.83 & 48.67 \\
\hline 25 & HUR 2-1 & 97 & 139 & 92.50 & 5 & 89.0 & 24.77 & 22.37 & 16.90 & 35.14 & 48.00 \\
\hline 26 & GR-32 & 120 & 145 & 169.41 & 7 & 84.0 & 35.10 & 17.79 & 17.89 & 37.69 & 45.00 \\
\hline 27 & HUR 917 & 114 & 139 & 93.77 & 8 & 88.0 & 22.00 & 20.67 & 19.41 & 37.72 & 51.67 \\
\hline 28 & IET-22202 & 79 & 108 & 113.95 & 8 & 79.0 & 30.73 & 25.75 & 20.70 & 42.92 & 48.33 \\
\hline 29 & URG-5 & 80 & 107 & 89.10 & 6 & 64.0 & 26.45 & 22.77 & 15.54 & 29.71 & 52.33 \\
\hline 30 & URG-42 & 96 & 122 & 100.96 & 5 & 61.0 & 25.84 & 20.80 & 16.80 & 37.19 & 45.00 \\
\hline 31 & URG-1 & 85 & 111 & 79.87 & 4 & 79.0 & 24.74 & 20.37 & 12.13 & 26.43 & 45.67 \\
\hline 32 & URG-30 & 82 & 110 & 101.70 & 4 & 64.0 & 21.56 & 20.33 & 11.93 & 25.95 & 46.00 \\
\hline 33 & URG-8 & 79 & 106 & 81.63 & 5 & 61.0 & 22.42 & 22.17 & 12.87 & 26.92 & 47.67 \\
\hline 34 & URG-19 & 82 & 109 & 134.35 & 6 & 79.0 & 28.32 & 24.10 & 18.25 & 38.97 & 47.00 \\
\hline 35 & URG-22 & 85 & 110 & 141.78 & 5 & 72.0 & 26.68 & 21.07 & 20.28 & 43.11 & 47.33 \\
\hline 36 & BG-102 & 85 & 109 & 124.35 & 5 & 67.0 & 25.63 & 24.50 & 10.74 & 23.38 & 46.00 \\
\hline 37 & ADAMCHINI & 120 & 150 & 159.40 & 6 & 84.0 & 24.90 & 16.05 & 13.86 & 30.97 & 44.67 \\
\hline 38 & PANTDHAN-12 & 92 & 117 & 99.86 & 7 & 81.0 & 30.65 & 25.15 & 17.56 & 37.83 & 46.33 \\
\hline 39 & IET-22225 & 94 & 123 & 108.93 & 6 & 76.0 & 25.20 & 23.70 & 16.69 & 34.88 & 47.67 \\
\hline 40 & IET-20556 & 99 & 127 & 135.37 & 6 & 78.0 & 28.80 & 22.63 & 17.35 & 35.71 & 48.33 \\
\hline 41 & IR-36 & 92 & 119 & 92.61 & 6 & 71.0 & 25.42 & 25.65 & 21.37 & 44.97 & 47.67 \\
\hline 42 & IR-64 & 91 & 118 & 90.79 & 7 & 77.0 & 25.79 & 22.25 & 23.51 & 47.01 & 50.00 \\
\hline 43 & URG-3 & 80 & 108 & 87.34 & 5 & 64.0 & 24.82 & 20.10 & 16.03 & 35.39 & 45.33 \\
\hline 44 & URG-24 & 82 & 108 & 150.97 & 5 & 75.0 & 26.10 & 19.87 & 18.64 & 43.73 & 42.67 \\
\hline 45 & BD-105 & 85 & 111 & 93.72 & 8 & 85.0 & 21.28 & 21.93 & 17.71 & 30.99 & 48.33 \\
\hline 46 & HUR 5-2 & 95 & 122 & 94.17 & 7 & 74.0 & 28.17 & 22.30 & 20.14 & 38.32 & 52.33 \\
\hline 47 & CGZR-1 & 84 & 112 & 103.00 & 7 & 87.0 & 21.47 & 20.65 & 19.50 & 37.31 & 53.00 \\
\hline 48 & R-RHZ-7 & 107 & 139 & 88.00 & 5 & 86.0 & 19.40 & 18.28 & 14.63 & 42.31 & 34.67 \\
\hline
\end{tabular}




\begin{tabular}{|l|l|c|c|c|c|c|c|c|c|c|c|}
\hline $\mathbf{4 9}$ & NDR-2104 & 96 & 119 & 104.43 & 6 & 79.0 & 25.47 & 20.39 & 16.50 & 40.60 & 41.33 \\
\hline $\mathbf{5 0}$ & NDR-2064 & 98 & 120 & 131.67 & 5 & 66.0 & 27.47 & 21.42 & 20.29 & 42.71 & 47.67 \\
\hline & Mean & $\mathbf{9 4}$ & $\mathbf{1 2 1}$ & $\mathbf{1 1 0 . 5 9}$ & $\mathbf{6}$ & $\mathbf{7 7 . 1}$ & $\mathbf{2 6 . 0 0}$ & $\mathbf{2 2 . 4 3}$ & $\mathbf{1 7 . 9 3}$ & $\mathbf{3 7 . 0 8}$ & $\mathbf{4 7 . 9 3}$ \\
\hline & C.V.(\%) & 1.0213 & 1.066 & 1.1908 & 14.37 & 2.357 & 3.2399 & 3.0263 & 6.6916 & 7.0168 & 6.1034 \\
\hline S.E. & 0.5515 & 0.7448 & 0.7603 & 0.497 & 1.0491 & 0.4864 & 0.3918 & 0.6929 & 1.5023 & 1.6891 \\
\hline C.D. 5\% & 1.5478 & 2.0903 & 2.1338 & 1.396 & 2.9443 & 1.365 & 1.0996 & 1.9445 & 4.216 & 4.7403 \\
\hline C.D. 1\% & 2.0489 & 2.767 & 2.8246 & 1.848 & 3.8975 & 1.8069 & 1.4556 & 2.574 & 5.5809 & 6.2749 \\
\hline & Range Lowest & 78 & 106 & 79.87 & 4 & 61.0 & 19.40 & 16.05 & 10.74 & 23.38 & 34.67 \\
\hline & Range Highest & 120 & 150 & 199.39 & 8 & 89.0 & 35.10 & 26.90 & 24.63 & 49.36 & 53.33 \\
\hline
\end{tabular}

\section{Plant biomass (g)}

The value for biomass varied from $23.38 \mathrm{~g}$ to $49.36 \mathrm{~g}$. The highest biomass was registered in genotype TYPE 3 (49.36 g) and lowest was BG-102 (23.38 g). The mean for this trait was value with $37.08(\mathrm{~g})$.

\section{Harvest index \%}

The value for HI was ranged from $34.67 \%$ to $53.33 \%$. The highest harvest index was registered in genotype ANJALI (53.33\%) and lowest was in R-RHZ 7 (34.67\%). The mean for this trait was value with $47.93 \%$.

Genetic variability and heritability and genetic advance parameters

The results pertaining to phenotypic coefficient of variation (PCV), genotypic coefficient of variation (GCV), heritability (broad sense) and genetic advance expressed as percent of mean for all the characters under study are presented in Table 3.

\section{Phenotypic and genotypic coefficient of variation}

The ANOVA presented in Table 2 revealed considerable variations over the traits under study exhibiting a wide range of phenotypic as well as genotypic coefficient of variation. In general, the values of phenotypic coefficient of variance were higher than those of genotypic coefficient of variance. The relative magnitudes of the phenotypic as well as genotypic variances between the traits were compared based on the phenotypic and genotypic coefficient of variation. PCV was recorded highest for plant height (22.93) followed by effective tillers/plant (21.60) and biomass per plant (18.35). Low magnitude of PCV was exhibited by harvest index (9.28) followed by 1000 grain weight (9.99) and days to maturity (10.16).

Rest other traits exhibited medium values of PCV. Similarly, GCV was also high for plant height (22.90) followed by biomass (16.96) and grain yield per plant (16.77). Whereas, low magnitude of GCV was exhibited by harvest index (6.99) followed by 1000 grain weight (9.52) and days to maturity (10.10).

The differences between the values of PCV and GCV were small for almost all the traits indicating less influence of environment in expression of these traits. However, the differences was comparatively greater in case of harvest index (2.29) followed by biomass (1.39).

\section{Heritability}

In the present study, heritability (broad sense) ranged from $55 \%$ to $99 \%$. The highest heritability was found in days to $50 \%$ flowering, days to maturity and plant height (99\%) followed by spikelet fertility (95\%) and panicle length (93\%). Lowest heritability was observed in effective tillers/plant (55\%) followed by harvest index $(56 \%)$. Other traits showed intermediate heritability. 


\section{Genetic advance}

Genetic advance as percent of mean $(5 \%)$ was realized highest for plant height (47.12) followed by biomass (32.29) and grain yield per plant (32.10). Lowest value was observed in harvest index (10.85) followed by 1000 grain weight (18.69) and days to maturity (20.70).

The studies of variance among 50 genotypes for ten characters revealed that the genotypes differed significantly for all the characters which suggested that the materials selected for the studies might be of diverse origin. Several workers have reported the presence of variability in and amongst the genotypes of rice for different traits. These findings are in accordance with the findings of Shobha et al., (2001), Yadav (2002) and Paikhomba et al.,(2014).The early flowering and maturity was seen in three genotypes namely NDR-97, IET-22202, URG-8 and N-22 while genotypes Adamchini and Swarna exhibited late flowering and maturity suggesting that short duration genotypes like NDR-97, IET22202, URG-8 and N-22 can be used for evolving early maturity or short duration rice suitable for rainfed areas. Several workers Viraktamath (1987) also reported positive as well as negative value for earliness in rice genotypes. The negative significant value for plant height is desirable because dwarf plant stature is essential to develop semi-dwarf high yielding varieties which are believed to be lodging resistant. The highest mean performance for plant height was observed in genotype Khutadhan and lowest in URG-8. Similar observations for plant height were also reported by Mitra (1962), Srivastava and Seshu (1982), and Singh et al., (2015) in rice. Higher number of tillers per plant contributes to higher grain yield. Genotype Swarna, MTU-1010, HUR 917 and Rajendra Kasthuri had highest mean performance for effective tillers and lowest mean performance for effective tillers in genotype URG-1 and URG14. Genotypes GR-32 and Akshyadhan had highest mean performance for panicle length and lowest in genotype R-RHZ-7 and BD105. Highest Spikelets fertility \% was observed in genotype Dantheshwari and HUR-2-1. The highest 1000 grain weight was registered in genotype Baranideep. Grain yield per plant in positive direction is desirable as higher grain yield is the main objective for almost all the breeding programmes. Highest grain yield per plant was observed in genotype Swarna (MTU7029) whereas lowest grain yield was observed in genotype BD-102. Many workers Roy et al., (2009), Priyanka et al., (2014) and Venkanna et al., (2014) have reported significant positive as well as negative heterosis for grain yield per plant in rice. The highest biomass was registered in genotype Type-3 and lowest was BD 102, the highest harvest index was also registered in genotype Anjali and lowest was R-RHZ-7. Sharma et al., (2013) and Singh et al., (2015) have also reported the similar observations for biomass and harvest index in their genotypes.

The magnitude of genetic variability decides the effectiveness of selection. It is an established fact that greater the variability among the genotypes better is the chance for further improvement in the crop. But this variability can be utilized better if it is heritable. The heritable portion of the overall observed variation can be ascertained by studying the components of variation such as GCV, PCV, heritability and predicted genetic advance. In this study, the estimates of PCV were higher than their corresponding GCV for all the traits studied. These findings were similar to the findings of Souroush et al., (2004) and Singh et al., (2015). The highest PCV and GCV were high recorded for sterile spikelets per panicle followed by grains yield per plot and grains yield per plant indicating that these traits were under the major 
influence of genetic control and less variable due to environmental factors. Therefore, such traits are important for further improvement. These findings are in close agreement with the researchers Anjaneyulu et al., (2010) and Singh et al., (2015). In the present study traits such as canopy temperature depression followed by chlorophyll content, days of maturity had low estimates of PCV and GCV indicating that selection for these traits will be less effective in comparison to remaining traits. The GCV provides a measure of comparison of variability and sometimes give some indication regarding validity of traits for selection. However, it does not provide clean picture of the extent of genetic gain to be expected from selection of phenotypic traits, unless heritable fraction of variation (heritability) is known (Burton, 1952). The difference between the values of PCV and GCV were small for almost all the traits indicating less influence of environment in expression of these traits suggesting phenotypic differences may be considered as genetic difference among genotypes for selection. However, the difference was comparatively greater in case of stomatal conductance followed by effective tillers and tiller per plant. This cautions that per-se performance of these traits should not be taken directly as the basis of selection other variability parameter for these traits such as heritability may also be taken into consideration.

The relative magnitude of genotypic and phenotypic variances for the traits is the broad sense heritability and it is used as analytical role in selection procedures. In the present investigation, high heritability was recorded for most of the characters except spikelet fertility per cent and number of effective tillers. Days to $50 \%$ flowering and days to maturity exhibited highest heritability followed by panicle length and total grains per panicle. Similar results were obtained by
Verma et al., (2000), Mahto et al., (2003), Aktar et al., (2004) and Lingaiah (2015) in rice genotype they studied. This indicated that selection of these traits would be more effective as compared to others.

High heritability does not always indicate high genetic gain. Heritability and genetic advance are important selection parameters. Heritability estimates along with genetic advance are normally more helpful in predicting the gain under selection than heritability estimates alone. It is not necessary that a character showing high heritability will also exhibit high genetic advance. The breeder should be cautious in making selection based on heritability as it indicates both additive and non-additive gene action.

Thus, heritability values coupled with genetic advance would be more reliable and useful in formulating selection procedure as it indicates that most likely the heritability is due to additive gene effects. In the present set of materials, high heritability coupled with high genetic advance as percent was recorded for panicle weight, total grains per panicle and filled grains per panicle indicating effectiveness of selection for the improvement of these traits while high heritability coupled with low genetic advance as percent of mean were observed for panicle length, days to maturity and days to $50 \%$ flowering which is indicative of non-additive gene action. High heritability coupled with high genetic advance may be attributed to additive gene action (Khan, 1990). The high heritability is being exhibited due to favorable influence of environment rather than genotype and selection for such traits may not be rewarding. These results are in conformity with the findings of Krishna et al., (2010), Singh et al., (2015) and Sawarkar and Senapati (2014).

The major findings and implications of the present study can be summarised as follows: 
Analysis of variance for 50 rice genotypes with regards to yield and yield components revealed that the existence of significant differences among the genotypes studied for all the traits.

The PCV value was recorded highest for plant height (22.93) followed by effective tillers/ plant (21.60) and biomass per plant (18.35). Low magnitude of PCV was exhibited by harvest index (9.28) followed by 1000 grain weight (9.99) and days to maturity (10.16).

The GCV value was high for plant height (22.90) followed by biomass (16.96) and grain yield per plant (16.77). Whereas, low magnitude of GCV was exhibited by harvest index (6.99) followed by 1000 grain weight (9.52) and days to maturity (10.10). The differences between the values of PCV and GCV were small for almost all the traits indicating less influence of environment in expression of these traits.

Heritability (broad sense) ranged from 55\% to $99 \%$. The highest heritability was found in days to $50 \%$ flowering, days to maturity and plant height (99\%) followed by spikelet fertility (95\%) and panicle length (93\%). Lowest heritability was observed in effective tillers/plant $(55 \%)$ followed by harvest index $(56 \%)$. Other traits showed intermediate heritability. Genetic advance as percent of mean (5\%) was realized highest for plant height (47.12) followed by biomass (32.29) and grain yield per plant (32.10). Lowest value was observed in harvest index (10.85) followed by 1000 grain weight (18.69) and days to maturity (20.70).

\section{References}

Akinwale MGG, Gregorio F, Nwilene BO, Akinyel SA, Ogunbayo and Odiyi AC, Heritability and correlation coefficient analysis for yield and its components in rice (Oryza sativa L.), African Journal of Plant Science, 5 (3), 207-212, 2011.

Akter K, Iftekharuddaula KM, Bashar MK, Kabir MH and Sarkar MZA, Genetic variability, correlation and path analysis in irrigated hybrid rice, Journal of Subtropical Agricultural Research and Development, 2(1): 17-23, 2004.

Anjaneyulu, M., Reddy, D. R. and Reddy, K. H. P. (2010). Genetic variability, heritability and genetic advance in rice (Oryza sativa L.). Research on Crops. 11(2): 415-416.

Directorate of Economics and Statistics, 2017 Ezuka A and Kaku H, A historical review of bacterial blight of rice, Department of Genetic Resources II and I, Bull. Nat. Inst. Agrobiol. Resour. 15, 1-207, 2000.

FAO, Food and Agriculture Organization of the United Nation, http://faostat.fao. org/site/339/default.aspx, 2017.

Krishna T, Kavita A and Pushpalata T, Genetic variability, heritability and genetic advance for quantitative traits in rice (Oryza sativa L.) accession, Agricultural and Biological Research, 26(1), 13-19, 2010.

Lu BR, Zheng KL, Qian HR and Zhuang J, Genetic differentiation of wild relatives of rice as referred by the RFLP analysis, Theor Appl Genet, 106,101- 106, 2002.

Madhavilatha LR, studies on anther culture and heterosis in aromatic $\mathrm{x}$ nonaromatic rice (Oryza sativa L.) hybrids, Thesis, IAS, BHU, 2007.

Mahto RN, Yadav MS and Mohan KS Genetic variation, character association and path analysis in rainfed upland rice. Indian Journal of Dryland Agricultural Research and Development, 18(2), 196198, 2003.

Mitra GN, Hybrid vigour and inheritance of height in rice, Nature, 194(2), 707-708, 1962.

Paikhomba N, Kumar A, Chaurasia AK and Rai PK, Assessment of Genetic 
Parameters for Yield and Yield Components in Hybrid Rice and Parents, Journal of Rice Research, 2(1), 117, 2014.

Priyanka K, Jaiswal HK and Waza SA, Combining ability and heterosis for yield, its component traits and some grain quality parameters in rice (Oryza sativa L.), Journal of Applied and Natural Science, 6(2), 495-506, 2014.

Roy SK, Senapati BK, Sinhamahapatra SP and Sarkar KK, Heterosis for yield and quality traits in rice, Oryza, 46(2), 8793, 2009.

Sabesan T, Saravanan K and Anandan A, Genetic divergence analysis for certain yield and quality traits in rice (Oryza sativa $\mathrm{L}$.) grown in irrigated saline low land of Annamalainagar, South India. Journal of Central European Agriculture, 10(4): 405-410. 2009.

Sawarkar A and Senapati BK, Polygenic variations and cause effect relationship in some photo-insensitive recombinant inbred lines (RILs) of Basmati derivative. African Journal of Biotechnology, 13(1), 112-118, 2014.

Sharma SK, Singh SK, Nandan R, Amita Sharma, Ravinder Kumar, Kumar V, Singh MK, Estimation of heterosis and inbreeding depression for yield and yield related traits in rice (Oryza sativa L.), Molecular Plant Breeding, 29(4), 238-246, 2013.

Shobha Rani N, Subba Rao LV, Viraktamath BC and Mishra B, National guidelines for the conduct of tests for distinctness, uniformity and stability - Rice (Oryza sativa L.), DRR Technical Bulletin, 8, 24, 2001.

Singh RK and Chaudhary BD, Biometrical Methods in Quantitative Genetic Analysis, Kalyani publishers, New Delhi, 178-185, 1985.

Singh SK, Vikash Sahu, Amita Sharma and Pradeep Kumar Bhati, Heterosis for yield and yield components in rice (Oryza sativa L.), Bioinfolet, 10(2), 752-761, 2013.

Souroush HR, Mesbah M, Hossainzadeh A and Bozorgipour R, Genetic and phenotypic variability and cluster analysis for quantitative and qualitative traits of rice, Seed and Plant, 20(2), 167-182, 2004.

Srivastava MN and Seshu DV, Heterosis in rice involving parents with resistance for various stresses. Oryza, 19(1), 172177, 1982.

Venkannan V, Raju Ch S, Lingaiuh $\mathrm{N}$ and Roa VT, Studies on heterosis and inbreeding depression for grain yield and grain quality traits in rice (Oryza sativa L.). Internationa Journal of Science, Environment and Technology, 3(3), 910-916, 2014.

Verma RS, Yadav RDS and Giri SP, Genetics of yield and its important components in rice (Oryza sativa L.), Crop Res. 31, 142-146, 2006.

Yadav PN, Chauhan MP and Singh RS, Genetic variability, heritability and expected genetic advance for certain qualitative characters in rice, New Agriculture, 13(112), 84-94, 2002.

\section{How to cite this article:}

Singh, S.K., Prudhvi Raj Vennela, Rajesh Singh, Varsha Gayatonde and Singh, D.K. 2018. Studies on Character Association, Path Analysis and Genetic Variability in Rice (Oryza sativa) Genotypes. Int.J.Curr.Microbiol.App.Sci. 7(05): 2702-2712.

doi: https://doi.org/10.20546/ijcmas.2018.705.313 